\title{
Stinging Nettles of Florida: Cnidoscolus ${ }^{1}$
}

Wendy B. Zomlefer ${ }^{2}$

\section{Classification}

Scientific Name: Cnidoscolus stimulosus (Michx.) Engelm. \& A. Gray

Common Name(s): bull-nettle, tread-softly, finger-rot, spurge-nettle

Family: Euphorbiaceae (spurge family)

\section{Description}

Perennial herbs covered with stinging hairs, milky sap, and tuberous roots. Stems erect to reclining, to $1 \mathrm{~m}$ ( $3 \mathrm{ft}$.) tall, but usually shorter, branched or unbranched. Leaves alternate, bright green to dark green, irregularly and deeply 3 - to 5-palmately divided (like a hand), coarsely toothed, 8-30 cm (3-12 in.) long and wide; leaf stalks (petioles) usually long. Flowers unisexual (male and female in the same cluster), $1.5 \mathrm{~cm}$ (0.5 in.) wide, with 5 white, petal-like structures (calyx lobes) and tubular base $1.5 \mathrm{~cm}$ (0.5 in.) long; several arranged in forked clusters terminating the stem. Capsule oval in outline, 3-parted, $1.5 \mathrm{~cm}$ (0.5 in.) long, explosively dehiscing to release 3 seeds; seeds oval in outline, 6 $\mathrm{mm}$ (0.25 in.) long, dark brown, mottled, with conspicuous swelling (caruncle) at one end. (Fig. 1).

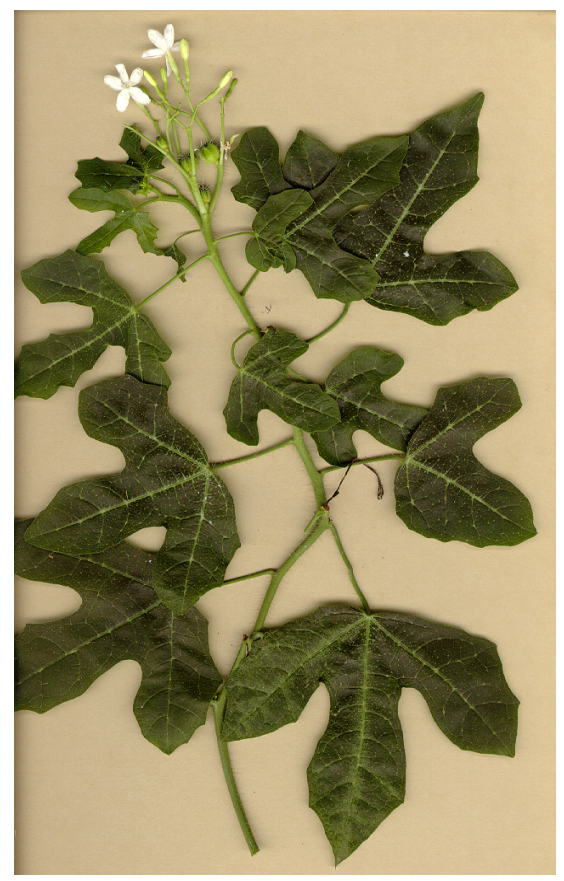

Figure 1. Whole flowering plant of Cnidoscolus stimulosus (bull-nettle). Credits: Photo by Kent D. Perkins.

Field Recognition Features: Erect plants covered with stiff stinging hairs; palmately 3- to 5-lobed leaves, conspicuous tubular-based white

1. This document is Fact Sheet HB-003, one of a series of the University of Florida Herbarium, Florida Cooperative Extension Service, Institute of Food and Agricultural Sciences. First publication date: May 2006; revised October 2008. Please visit the EDIS Web site at http://edis.ifas.ufl.edu and the Herbarium Web site at http://www.flmnh.ufl.edu/herbarium/.

2. Wendy B. Zomlefer, Curator of the Herbarium, University of Georgia Herbarium (GA), Dept. of Plant Biology, 2502 Plant Sciences, Athens, GA 30602 (former Extension Botanist, University of Florida Herbarium). Contact : Kent D. Perkins, University of Florida Herbarium, Florida Museum of Natural History, 379 Dickinson Hall, P.O. Box 110575, Gainesville, FL, 32611-0575.

The Institute of Food and Agricultural Sciences (IFAS) is an Equal Opportunity Institution authorized to provide research, educational information and other services only to individuals and institutions that function with non-discrimination with respect to race, creed, color, religion, age, disability, sex, sexual orientation, marital status, national origin, political opinions or affiliations. U.S. Department of Agriculture, Cooperative Extension Service, University of Florida, IFAS, Florida A. \& M. University Cooperative Extension Program, and Boards of County Commissioners Cooperating. Larry Arrington, Dean 
flowers in a cluster terminating the stem; 3-parted bristly capsule with 3 mottled seeds. Blooming all year in FL.

Distribution: FL: native; nearly throughout the state. General: along the Coastal Plain from se VA to s FL, w to MS and e LA.

Habitat: Dry, often sandy areas such as sandhills, dry woods, beaches, scrub, and disturbed areas (such as roadsides, fields, and lawns).

\section{Similar Species}

None, although species of Urtica (true stinging nettles) also have stinging hairs (see Comments below).

\section{Toxicity}

Irritant compounds that cause intense stinging and itching fill the long, stiff, hollow hairs on the stem, leaves, flowers, and fruits (Fig. 2). Although not intensively studied, the injection mechanism may be similar to that in Urtica species: each hair ends in a blunt tip that breaks off, permitting injection of the poison into the skin. Often a rash (or tiny red bumps) appear after the burning sensation wears off (usually less than 30 minutes). In sensitive individuals, the rash or dull purplish discoloration may persist for several days.

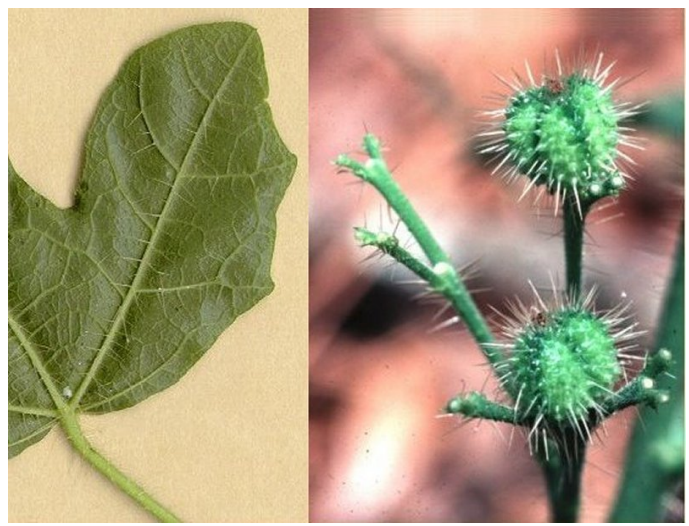

Figure 2. Stinging hairs of Cnidoscolus stimulosus. Left: leaf underside; Right: close-up of fruit. Credits: Left: Photo by Kent D. Perkins; Right: Photo by Walter S. Judd.

\section{Economic Uses}

The starchy, tuberous roots are edible when cooked and taste like white potato. However, excavating the roots requires care since touching the above-ground plant parts (covered with stinging hairs) must be avoided. The milky sap has been used in herbal medicine.

\section{Comments}

The unrelated true nettles (species of Urtica) also have stinging hairs but are characterized by trailing weak stems, opposite triangular leaves, and minute greenish flowers and fruit in congested clusters. A plant fact sheet for these species is also available.

\section{Selected References}

- Morton, J. F. 1974. Folk Remedies of the Low Country. E. A. Seaman Publishing, Inc., Miami, Florida.

- __ 1974. Wild Plants for Survival in south Florida. Trend House, Tampa, Florida.

- __ 1982. Plants Poisonous to People in Florida and other warm Areas. Published by the author, Stuart, Florida.

- Perkins, K. D. \& W. W. Payne. 1981 [reprint]. Guide to the poisonous and irritant plants of Florida. Circular 441, Florida Cooperative Extension Service, Institute of Food and Agricultural Sciences, Univ. Florida, Gainesville.

- Webster, G. L. 1967. The genera of the Euphorbiaceae in the southeastern United States. J. Arnold Arbor. 48: 303-430.

- Wunderlin, R. P. and B. F. Hansen. 2003. Guide to Vascular Plants of Florida. 2nd ed. University Press of Florida, Gainesville. 